\title{
PENGEMBANGAN INSTRUMEN ASESMEN YANG BERPUSAT PADA SISWA DALAM PEMBELAJARAN FISIKA
}

\author{
Wulan Trisnawaty ${ }^{1)}$ \\ Muslimin Ibrahim ${ }^{2}$ \\ Bambang Soebali Wihono ${ }^{2)}$ \\ ${ }^{1)}$ Mahasiswa Pascasarjana Universitas Negeri Surabaya \\ ${ }^{2)}$ Dosen Pascasarjana Prodi Pendidikan Sains Universitas Negeri Surabaya
}

\begin{abstract}
The aims of this research was developing an assessment instrument based on student center on physics learning. The development of this assessment used $4 D$ models and has been implemented in students of $X^{\text {th }}$ grade at Sejahtera Senior High School using One Shot Case Study design. The research revealed that the development of assessment instrument has validity with category deserves to use; the questions in the cognitive test has high reliability; the difficult of the questions get in proportion; and the sensitivity of the questions include sensitive. The correlation of assessment between student and teacher in cognitive test, skills of science process test, honesty and cooperation characters were in high corelation. Students also gived positive responses to this instrument. Based on those findings, it could be concluded that the assessment instrument based on student center deserves to use in physics learning.
\end{abstract}

Key Word: assessment based on student center

Abstrak: Penelitian ini bertujuan untuk mengembangkan instrumen asesmen berpusat pada siswa dalam pembelajaran fisika. Pengembangan asesmen menggunakan model pengembangan 4D dan diujicobakan pada siswa kelas X di SMA Sejahtera Surabaya. Desain penelitian menggunakan One Shot Case Study. Dari hasil penelitian diperoleh beberapa temuan, yaitu: instrumen asesmen yang dikembangkan memiliki rata-rata skor validitas berketegori layak digunakan; soal yang digunakan pada tes kognitif memiliki derajat reliabilitas yang tinggi; tingkat kesukaran soal cukup proporsional; serta sensitivitas butir soal yang tergolong sensitif. Kesesuaian penilaian siswa dengan guru pada tes kognitif, tes keterampilan proses sains, serta pada penilaian karakter kejujuran dan kerjasama termasuk kategori sangat tinggi. Respon yang diberikan siswa pada instrumen ini sangat positif. Berdasarkan hasil penelitian dapat disimpulkan bahwa instrumen asesmen yang berpusat pada siswa dalam pembelajaran fisika layak digunakan dalam pembelajaran.

Kata kunci: asesmen berpusat pada siswa

\section{PENDAHULUAN}

Peraturan Pemerintah Nomor 19 tahun 2005 tentang Standar Nasional Pendidikan Bab I pasal 1 menjelaskan bahwa kompetensi lulusan haruslah mencakup tiga hal yaitu sikap, pengetahuan, dan keterampilan. Ini berarti bahwa pembelajaran dan penilaian harus mengembangkan kompetensi peserta didik yang berhubungan dengan ranah afektif, kognitif, dan psikomotor. Asesmen, sebagai sarana untuk memperoleh informasi terhadap kegiatan pembelajaran yang sesuai dan memenuhi tujuan pembelajaran memungkinkan untuk mencakup ketiga ranah tersebut di atas.

Namun seiring dengan pergeseran paradigma pembelajaran dari aktivitas kelas yang berpusat pada guru (teacher center) menjadi berpusat pada siswa (student center) tidak hanya membawa dampak terhadap metode dan aktivitas belajar tetapi juga terhadap metode asesmen terhadap proses dan hasil pembelajaran itu sendiri. Oleh karena itu model asesmen yang digunakan hendaknya yang melibatkan dan berpusat pada siswa serta memenuhi fungsi perbaikan dan pemberdayaan siswa.
Kenyataan menunjukkan bahwa selama ini guru masih menggunakan tes tertulis dengan alasan pengkonstruksiannya lebih mudah dan penskorannya tidak membutuhkan waktu yang lama. Padahal, ketika kita melakukan asesmen menggunakan tes tertulis, kemampuan peserta didik yang diukur adalah kemampuan kognitif saja sedang kemampuan afektif dan psikomotor belum terukur, tetapi guru sudah dapat menyimpulkan bagaimana kemampuan peserta didik tersebut. Dengan demikian, sungguh tidak adil melakukan evaluasi dengan cara demikian.

Belakangan juga muncul berbagai interpretasi tentang bagaimana konstruksi pengetahuan itu terwujud pada peserta didik. Piaget (1995) mengatakan bahwa konstruksi makna terjadi melalui proses asimilasi dan akomodasi. Di lain pihak, Vygotsky (1995) mengatakan bahwa konstruksi pengetahuan terjadi melalui proses interaksi sosial dengan orang lain yang lebih mampu (dalam istilah Vygotsky: skilled individuals). Diyakini bahwa konstruksi makna akan terjadi jika proses akuisisi pengetahuan dilakukan dalam lingkungan sosial budaya yang sesuai. 
Berpijak dari hal-hal tersebut di atas, diperlukanlah suatu asesmen alternatif dalam suatu pembelajaran. Asesmen alternatif merupakan upaya memperbaiki dan melengkapi asesmen tradisional sehingga penilaian hasil belajar tidak hanya berhubungan dengan hasil akhir (end product) tetapi yang lebih penting merupakan bagian penting dalam proses pembelajaran..

Asesmen berpusat pada siswa ini diterapkan pada pembelajaran fisika sebab sangat sesuai dengan karakteristik dan ciri khusus dari fisika yang mempelajari gejala-gejala alam disertai hukum-hukum yang berhubungan dengan gejala tersebut, serta adanya praktikum-praktikum yang menyertainya sehingga keterampilan yang dinilai meliputi aspek kognitif, afektif, dan psikomotor.

Berdasarkan bahasan di atas, maka peneliti mencoba mengembangkan instrumen asesmen yang berpusat pada siswa dalam pembelajaran fisika.

\section{METODE PENELITIAN}

Penelitian ini merupakan penelitian pengembangan (developing research) karena mengembangkan instrumen penilaian berpusat pada siswa pada pembelajaran fisika. Subjek pada saat ujicoba adalah siswa kelas X SMA Sejahtera Surabaya tahun ajaran 2010-2011 dengan pemilihan subjek secara random sampling. Model yang digunakan dalam pengembangan ini adalah model $4 \mathrm{D}$ (Four D Model) yang meliputi pendefinisian (define), perancangan (design), pengembangan (develop), dan penyebaran (disseminate) yang dikembangkan oleh Thiagarajan (1974).

Dalam penelitian ini, desain ujicoba menggunakan rancangan eksperimen model One Shot Case Study karena hanya menggunakan satu kelas eksperimen tanpa adanya pembanding dan juga tanpa tes awal. Pada penelitian ini diberikan perlakuan terhadap kelas eksperimen untuk mengetahui pengaruh dari perlakuan tersebut.

Desain penelitian ini digambarkan sebagai berikut: (Arikunto, 2009:212)

$$
\mathrm{X} \longrightarrow \mathrm{O}_{1}
$$

Keterangan:

$\mathrm{X}=$ Perlakuan yaitu kegiatan pembelajaran fisika materi elastisitas dan gaya pegas yang dilakukan oleh guru.

$\mathrm{O}_{1}=$ Tes yang dilakukan untuk memperoleh skor/nilai tes setelah memberikan perlakuan dengan menggunakan instrumen asesmen berpusat pada siswa yang telah dikembangkan.

Metode pengumpulan data dilakukan dengan cara observasi, pemberian tes, dan penyebaran angket. Kemudian hasil tersebut dianalisis secara deskriptif kualitatif dan statistik inferensial dengan menggunakan uji korelasi pada program SPSS 16.0.

\section{HASIL PENELITIAN}

Berdasarkan hasil ujicoba dalam penelitian, diperoleh hasil sebagai berikut.

\section{Reliabilitas Soal}

Reliabilitas soal telah diujicobakan pada kelas $\mathrm{X}$ untuk menunjukkan apakah instrumen tersebut dapat dipercaya atau tidak. Dengan menggunakan rumus Alpha (Ratumanan dan Laurens, 2006) maka diperoleh nilai koefisien reliabilitas sebagai berikut:

$\begin{array}{ccc}\begin{array}{c}\text { Subjek } \\ \text { ujicoba }\end{array} & \begin{array}{c}\text { Koefisien } \\ \text { Reliabilitas }\end{array} & \text { Kategori } \\ \text { Ujicoba I } & 0.88 & \begin{array}{c}\text { Reliabilitas } \\ \text { tinggi }\end{array} \\ \begin{array}{c}\text { Ujicoba II } \\ \text { kelas X-2 }\end{array} & 0.80 & \begin{array}{c}\text { Reliabilitas } \\ \text { tinggi }\end{array} \\ \begin{array}{c}\text { Ujicoba II } \\ \text { kelas X-4 }\end{array} & 0.82 & \begin{array}{c}\text { Reliabilitas } \\ \text { tinggi }\end{array}\end{array}$

Dengan demikian dapat dinyatakan bahwa item soal tersebut memiliki derajat reliabilitas yang tinggi dan konsisten. Artinya, kapanpun alat penilaian tersebut digunakan akan memberikan hasil yang relatif sama.

2. Tingkat Kesukaran Butir Soal

Berdasarkan analisis tingkat kesukaran butir soal diperoleh hasil sebagai berikut.

\begin{tabular}{|c|c|c|c|c|c|c|}
\hline \multirow{2}{*}{$\begin{array}{l}\text { Kri } \\
\text { teri } \\
\text { a }\end{array}$} & \multicolumn{2}{|c|}{ Ujicoba I } & \multicolumn{2}{|c|}{$\begin{array}{c}\text { Ujicoba II Kelas } \\
\qquad \text { X-2 }\end{array}$} & \multicolumn{2}{|c|}{ Ujicoba II Kelas X-4 } \\
\hline & $\begin{array}{l}\text { Jumla } \\
\text { h Item } \\
\text { Soal }\end{array}$ & $\begin{array}{l}\text { Nome } \\
\text { r Item } \\
\text { Soal }\end{array}$ & $\begin{array}{l}\text { Jumla } \\
\text { h Item } \\
\text { Soal }\end{array}$ & $\begin{array}{l}\text { Nome } \\
\text { r Item } \\
\text { Soal }\end{array}$ & $\begin{array}{l}\text { Jumla } \\
\text { h Item } \\
\text { Soal }\end{array}$ & $\begin{array}{l}\text { Nomer } \\
\text { Item Soal }\end{array}$ \\
\hline $\begin{array}{l}\text { Suk } \\
\text { ar }\end{array}$ & 1 & 9 & 2 & 9,10 & 3 & $9,10,16$ \\
\hline $\begin{array}{l}\text { Sed } \\
\text { ang }\end{array}$ & 9 & $\begin{array}{c}1,4, \\
7,8, \\
11, \\
13, \\
14, \\
15,16\end{array}$ & 10 & $\begin{array}{c}1,2, \\
3,4, \\
6,7 \\
13, \\
14, \\
15,16\end{array}$ & 11 & $\begin{array}{c}2,3,4,5,6 \\
7,8,11,13, \\
14,15\end{array}$ \\
\hline $\begin{array}{l}\mathrm{Mu} \\
\mathrm{dah}\end{array}$ & 4 & $\begin{array}{c}2,5 \\
10,12\end{array}$ & 4 & $\begin{array}{c}5,8, \\
11,12\end{array}$ & 2 & 1,12 \\
\hline $\begin{array}{l}\text { San } \\
\text { gat } \\
\mathrm{Mu} \\
\text { dah }\end{array}$ & 2 & 3,6 & - & - & - & - \\
\hline
\end{tabular}


Berdasarkan tabel tersebut dapat dilihat bahwa pada hasil ujicoba I maupun ujicoba II, tingkat kesukaran soal yang digunakan cukup proporsional. Hal ini disebabkan jumlah soal yang tingkat kesukarannya sedang, lebih banyak dibandingkan soal yang tingkat kesukarannya mudah. Dengan kata lain bahwa soal yang digunakan tidak terlalu mudah juga tidak terlalu sukar. Sehingga dapat dikatakan bahwa soal dalam instrumen asesmen berpusat pada siswa cukup proporsional.

3. Sensitivitas Soal

Sensitivitas soal tes hasil belajar kognitif yang diperoleh dapat dilihat pada tabel berikut.

$\begin{array}{ccc}\begin{array}{c}\text { Subjek } \\ \text { ujicoba }\end{array} & \begin{array}{c}\text { Koefisien } \\ \text { Reliabilitas }\end{array} & \text { Kategori } \\ \text { Ujicoba I } & 0.55 & \text { Soal sensitif } \\ \begin{array}{l}\text { Ujicoba II } \\ \text { kelas X-2 }\end{array} & 0.60 & \text { Soal sensitif } \\ \begin{array}{l}\text { Ujicoba II } \\ \text { kelas X-4 }\end{array} & 0.50 & \text { Soal sensitif }\end{array}$

Berdasarkan tabel tersebut, soal termasuk kategori sensitif. Artinya, soal tersebut dapat memberikan informasi bahwa hasil pengukuran merupakan akibat dari pembelajaran yang dilakukan.

4. Uji korelasi

Berdasarkan hasil uji korelasi yang dihitung menggunakan program SPSS 16.0 pada tes kognitif, tes keterampilan proses sains, maupun lembar penilaian karakter kejujuran dan kerjasama, maka diperoleh hasil sebagai berikut:

\begin{tabular}{cc}
\multicolumn{2}{c}{ Korelasi Tes Kognitif } \\
Subjek Ujicoba & $\begin{array}{c}\text { Koefisien } \\
\text { korelasi }\end{array}$ \\
Ujicoba I & 0.980 \\
Ujicoba II kelas X-2 & 0.984 \\
Ujicoba II kelas X-4 & 0.958
\end{tabular}

Korelasi Keterampilan Proses Sains

Koefisien
korelasi

Ujicoba I

0.897

Ujicoba II kelas X-2 $\quad 0.987$

Ujicoba II kelas X-4 $\quad 0.874$
Korelasi Penilaian Karakter Kejujuran

$$
\begin{array}{cc}
\text { Koefisien } \\
\text { korelasi }
\end{array}
$$

Ujicoba I $\quad 0.860$

Ujicoba II kelas X-2 $\quad 0.914$

Ujicoba II kelas X-4 $\quad 0.834$

Korelasi Penilaian Karakter Kerjasama

$$
\begin{array}{cc}
\text { Subjek Ujicoba } & \begin{array}{c}
\text { Koefisien } \\
\text { korelasi }
\end{array} \\
\text { Ujicoba I } & 0.918
\end{array}
$$

Ujicoba II kelas X-2 $\quad 0.909$

Ujicoba II kelas X-4 $\quad 0.928$

\section{PEMBAHASAN}

Pada tes kognitif, dilakukan analisis terhadap realibilitas, tingkat kesukaran, dan sensitivitas soal. Pada penelitian ini, soal yang digunakan berbentuk uraian sehingga menurut Ratumanan dan Laurens (2006), untuk mengetahui realibilitas tes bentuk uraian digunakan rumus Alpha. Berdasarkan hasil perhitungan, diperoleh nilai reliabilitas pada ketiga sampel penelitian masingmasing sebesar $0.88 ; 0.80$ dan 0.82 . Nilai tersebut menurut Ornstein (dalam Ratuman dan Laurens, 2006) termasuk dalam kategori reliabilitas tinggi. Hal ini berarti bahwa kapanpun alat penilaian tersebut digunakan akan memberikan hasil yang relatif sama. Selain itu, meskipun diujikan pada dua kelas yang berbeda, nilai reliabilitas yang diperoleh tetap konsisten, yaitu berada pada kategori tinggi. Hal ini dikarenakan sejak awal, peneliti sudah mengikuti prosedur yang sesuai untuk mengembangkan instrumen ini. Kemudian sebelum melakukan ujicoba, peneliti juga telah mengkonsultasikan instrumen tersebut kepada para pakar terlebih dahulu. Jadi dapat dikatakan bahwa instrumen asesmen yang dikembangkan termasuk reliabel.

Tingkat kesukaran soal dalam penelitian ini diperoleh hasil bahwa pada ujicoba 1 terdapat 1 soal yang tergolong sukar, 9 soal tergolong sedang, 4 soal tergolong mudah, dan 2 soal tergolong sangat mudah. Pada kelas X-2 hanya dua soal yang tergolong sukar, sepuluh soal termasuk kategori sedang, empat soal kategori mudah sedangkan pada kelas X-4 terdapat tiga soal yang tergolong sukar, sebelas soal termasuk kategori sedang, dan dua soal kategori mudah. Hal tersebut menunjukkan bahwa soal yang digunakan dalam instrumen asesmen yang dikembangkan cukup 
proporsional. Tingkat kesukaran suatu butir soal didefinisikan sebagai proporsi atau persentase subjek yang menjawab butir tes tertentu dengan benar. Asumsi yang digunakan untuk memperoleh soal yang baik, khususnya untuk tingkat kesukaran soal adalah adanya keseimbangan. Keseimbangan yang dimaksudkan adalah adanya soal-soal yang termasuk mudah, sedang, dan sukar secara proporsional. Namun berdasarkan tabel tersebut dapat juga kita amati bahwa baik pada hasil ujicoba 1 maupun hasil ujicoba 2, butir soal nomer 9 termasuk kategori sukar. Hal ini dikarenakan saat pembelajaran, guru hanya menjelaskan rumus yang digunakan untuk menghitung modulus elastisitas tanpa memberikan contoh penerapan pada soal sehingga saat menjumpai soal tentang cara menghitung modulus elastisitas suatu benda, siswa mengalami kesulitan.

Sensitivitas suatu tes adalah kemampuan tes tersebut untuk mengukur efek pembelajaran (Ibrahim, 2005). Pada ujicoba 1 diperoleh nilai sensitivitas sebesar 0.55 sedangkan pada ujicoba 2 diperoleh nilai sensitivitas butir soal sebesar 0.60 dan 0.50 seperti yang ditunjukkan pada Tabel 4.21. Dengan demikian dapat dikatakan bahwa soal yang digunakan sensitif. Artinya bahwa soal lebih banyak dijawab benar setelah pembelajaran daripada sebelum pembelajaran. Hal ini sesuai dengan penjelasan Kardi (2000:137) bahwa soal yang efektif adalah soal yang dijawab benar oleh siswa lebih banyak setelah berlangsungnya proses pembelajaran. Jadi hasil yang diperoleh siswa setelah proses pembelajaran merupakan akibat dari pembelajaran yang dilakukan.

Pada instrumen asesmen berpusat siswa yang dibuat, siswa diminta menilai diri mereka sendiri berdasarkan rubrik yang telah dikembangkan oleh peneliti. Rubrik ini berisi kriteria apa saja yang harus dinilai oleh siswa dan pedoman penskorannya. Kemudian hasil tersebut disesuaikan dengan hasil penilaian yang dilakukan oleh guru dengan menggunakan rubrik yang sama. Hasil kesesuaian antara siswa dan guru dianalisis dengan menggunakan program SPSS 16.0.

Kesesuaian penilaian antara siswa dan guru pada tes kognitif, tes keterampilan proses sains, maupun penilaian karakter kejujuran dan kerjasama diperoleh hasil bahwa seluruh subjek ujicoba memperoleh nilai korelasi dengan kategori sangat tinggi. Kesesuaian penilaian antara siswa dan guru menunjukkan bahwa siswa mampu menilai dirinya sendiri pada ranah kognitif, afektif, maupun psikomotor dengan menggunakan rubrik yang telah dikembangkan. Artinya bahwa instrumen asesmen yang dikembangkan dapat dipahami dengan baik oleh siswa sehingga dapat digunakan untuk melatih keterampilan menilai diri sendiri. Hal ini senada dengan penelitian yang dilakukan oleh James dan Jessica (2008) yang menyimpulkan bahwa asesmen dapat melatihkan keterampilan siswa dalam memonitor diri sendiri, melatihkan kepercayaan diri, meningkatkan pemahaman, mengidentifikasi kemajuan belajar, dan menghasilkan strategi belajar sehingga dapat meningkatkan motivasi dan prestasi siswa. Hal ini berimplikasi bahwa asesmen tidak hanya melalui pengukuran dan penguatan terhadap hasil belajar, akan tetapi lebih ke arah penguatan pengembangan strategi-strategi, sikap-sikap, keterampilan-keterampilan, dan proses kognitif yang esensial untuk pembelajaran sepanjang hayat (Widodo, 2010).

Menurut Trianto (2009), keterampilan menilai diri sendiri ini sangat diperlukan dalam proses pembelajaran agar siswa dapat mengetahui kelemahan apa saja yang mereka miliki sehingga dapat ditentukan langkahlangkah apa saja yang harus dilakukan untuk memperbaiki kelemahan tersebut. Selain itu, dengan memberi kesempatan kepada siswa untuk terlibat dalam proses penilaian, guru telah membantu siswa dalam memahami tujuan pengalaman belajar dan kriteria keberhasilan. Ibrahim (2005) mengatakan bahwa metode asesmen dapat bekerja dengan efektif bilamana siswa tahu tujuan pengajaran dan kriteria untuk mengukur keberhasilan tujuan tersebut. Dengan mengetahui tujuan dan kriteria keberhasilan akan membantu siswa untuk memonitor kemajuan diri mereka sendiri.

\section{PENUTUP}

Berdasarkan hasil penelitian dan diskusi yang telah dijabarkan maka dapat diambil kesimpulan bahwa instrumen asesmen berpusat pada siswa pada layak digunakan dalam pembelajaran fisika.

\section{DAFTAR PUSTAKA}

Anderson, L.W. dan Krathwohl, D.R. 2001. A Taxonomy for Learning, Teaching, and Assessing. A Revision of Bloom's Taxonomy of Educational Objectives. Abridged Edition. New York: Addison Wesley Longman, Inc.

Arifin, Z. 2009. Membangun Kompetensi Pedagogis Guru Matematika (Landasan Filosofi, Histori, dan Psikologi). Surabaya: Lentera Cendikia.

Arikunto, S. 2006. Manajemen Pendidikan. Jakarta: PT Bumi Aksara.

Berk, R.A. 1986. Performance Assessment. Methods\&Applications. London: Hopkins University Press.

Bunut. 2007. Macam-macam Validitas. Blog Pribadi. Diakses melalui http://budid-pox.blogspot.com/ pada tanggal 25 Pebruari 2011.

Burke, B. 2004. School To Carrer: Reworking The Model. Technology And Learning. Proquest Educational Journal. Pg.26.

Clarke, S. 2005. Formative Assessment In Action Weaving The Elemements Together. London: Hodder Murray. 
Cohen, J. dan Swerdlik, M.E. 2004. Psychological Testing And Assessment: An Introduction To Test And Measurement. Sixth Edition. Boston: Illionois State University-Mcgraw Hill.

Depdiknas. 2005. Peraturan Pemerintah RI No 19 tahun 2005 Tentang Standar Nasional Pendidikan. Jakarta.

Direktorat Pembinaan Sekolah Menengah Kejuruan. 2008. Penilaian Hasil Belajar Sekolah Menengah Kejuruan. Jakarta.

Gaspersz, M. 2010. "Pengembangan Asesmen Berdasarkan Revisis Taksonomi Bloom Dalam Pembelajaran Matematika Untuk Materi Dimensi Tiga Pada Siswa Kelas X SMA”. Tesis Magister, Tidak Dipublikasikan. Surabaya: Program Pasca Sarjana Universitas Negeri Surabaya.

Glencoe. Tanpa tahun. Performance Assessment In The Science Clasroom. USA: McGraw-Hill.

Haryoko, S. 2009. Penerapan Asesmen Teman Sejawat Dalam Setting Pembelajaran Kolaboratif. Jurnal Pendidikan dan Kebudayaan, Vol 15, No. 4, Juli 2009. Surabaya.

Ibrahim, M. 2005. Asesmen Berkelanjutan. Konsep Dasar, Tahapan Pengembangan Dan Contoh. Surabaya: Unesa University Press.

Javaherbakhsh, M.R. 2010. The Impact Of SelfAssessment On Iranian EFL Learners' Writing Skill. Jurnal Akademik. Diakses melalui http://find.galegroup.com/gtx/retrieve.do?contentSe $\mathrm{t}=\mathrm{IAC}$ -

Documents\&resultListType $=$ RESULT_LIST\&qryS erId=Locale(en,,):FQE\%3D(KE,None,15)self+asse ssment:And:LQE\%3D(AC,None,8)fulltext\$\&sgHit CountType $=$ None $\&$ inPS $=$ true $\&$ sort $=$ DateDescend $\&$ searchType $=$ BasicSearchForm $\&$ tabID $=$ T002 \&pr odId=PROF\&searchId=R1\&currentPosition=7\&use rGroupName $=$ unesa $\&$ docId=A233712098\&docTyp e=IAC pada tanggal 20 September 2010.

Johnson, D.W. dan Johnson, R.T. 2002. Meaningful Assessment: A Manageable And Cooperative Process. Boston: Allyn \& Bacon.

Jovovich. 2007. Teori Validitas. Blog Pribadi. Diakses melalui

http://violetatniyamani.blogspot.com/2007/09/teorivaliditas.html pada tanggal 20 Oktober 2010.Unsilster. 2009. Pengertian Asesmen. Diakses melalui http://unsilster.com/2009/12/pengertianasesmen/ pada tanggal 18 Oktober 2010.

Kemp, J.E., Gary R.M., dan Steven M.R. 1994. Designing Effective Instruction. New York: Macmillan College Publishing Company.

Liu, E.Z.F. dan Yuan, S.M. 2003. A Study Of Student's Attitudes Toward And Desired System Requirements Of Networked Peer Assessment System. International Journal of Instructional Media Vol.30,Iss.4;pg.349,6 pgs. New York.

McMillan, J. dan Hern, J. 2008. Student Self-Assessment: The Key to Stronger Student Motivation and Higher Achievement. Virginia Commonwealth University.
Noonan, B. dan Randy, C. 2005. Peer and SelfAssessment in High School. Electronical Journal Vol 10, No 17, November 2005. University of Saskatchewan.

Nur, M. 2005. Asesmen Autentik. Makalah yang disampaikan pada Training Kegiatan Belajar Mengajar Inovatif SDK Masa Depan Cerah Tanggal 4, 14, dan 15 Oktober 2005 di Pusat Sains dan Matematika Sekolah Unesa. Surabaya.

Ratumanan, T.G dan Laurens. 2003. Evaluasi Hasil Belajar Yang Relevan Dengan Kurikulum Berbasis Kompetensi. Surabaya: Unesa University Press.

Rybacki, D. dan Lattimore, D. 1999. Assessment of Undergraduate and Graduate Programs. Jurnal online. Diakses melalui http://find.galegroup.com/gtx/retrieve.do?contentSe $\mathrm{t}=\mathrm{IAC}$ -

Documents\&resultListType=RESULT_LIST\&qryS erId=Locale(en,,):FQE\%3D(KE,None,24)definition +of+assessment:And:LQE\%3D(AC,None,8)fulltext $\$ \&$ sgHitCountType $=$ None $\&$ inPS $=$ true $\&$ sort $=$ DateD escend $\&$ searchType $=$ BasicSearchForm $\&$ tabID $=$ T0 02\&prodId=PROF\&searchId=R1\&currentPosition= 9\&userGroupName $=$ unesa \&docId=A55084060\&do cType=IAC pada tanggal 18 Oktober 2010.

Sudjana. 2009. Metode Statistika. Bandung: Tarsito.

Suhendar, E. 2010. Self Asessment Dalam Pembelajaran Fisika. Blog Fisika SMA Online. Diakses melalui http://fisikasma-online.blogspot.com/2010/02/selfassessment.html pada tanggal 21 November 2010.

Trianto. 2009. Mendesain Model Pembelajaran Inovatif Progresif, Konsep, Landasan dan Implementasinya pada Kurikulum KTSP. Surabaya: Kencana.

University of Technology Sydney. 2007. Peer Assessment. Diakses melalui http://translate.google.co.id/translate?hl=id\&langpa ir=en|id\&u=http://www.iml.uts.edu.au/assessment/s tudents/peer.html pada tanggal 20 September 2010.

Worsnop, C. 2010. Types of Assessment. Kanada: Media Awareness Network. Diakses melalui http://www.media-

awareness.ca/english/resources/educational/teachin g_backgrounders/media_literacy/types_of_assessm ent.cfm pada tanggal 20 Oktober 2010.

Zainal, M. 2008. Pengertian Asesmen, Bentuk Asesmen dan Langkah Penerapan Asesmen. Blog Pribadi. Diakses melalui http://meetabied.wordpress.com/2010/01/14/pengert ian-asesmen-bentuk-asesmen-dan-langkahpenerapan-asesmen/ pada tanggal 18 Oktober 2010.

Zulharman. 2007. Self dan Peer Assessement Sebagai Penilaian Formatif dan Sumatif. Diakses melalui http://zulharman79.wordpress.com/2007/05/29/selfdan-peer-assessment-sebagai-penilaian-formatifdan-sumatif/ pada tanggal 9 Pebruari 2011. 